\title{
Increased bacterial growth efficiency with environmental variability: results from DOC degradation by bacteria in pure culture experiments
}

\author{
M. Eichinger, R. Sempéré, G. Grégori, B. Charrière, J. C. Poggiale, and D. Lefèvre \\ Université de la Méditerranée, Laboratoire de Microbiologie Géochimie et Ecologie Marines (LMGEM) CNRS/INSU, \\ UMR 6117, Centre d'Océanologie de Marseille, Campus de Luminy, Case 901, 13288 Marseille Cedex 9, France
}

Received: 18 January 2010 - Published in Biogeosciences Discuss.: 1 February 2010

Revised: 21 May 2010 - Accepted: 26 May 2010 - Published: 4 June 2010

\begin{abstract}
This paper assesses how considering variation in DOC availability and cell maintenance in bacterial models affects Bacterial Growth Efficiency (BGE) estimations. For this purpose, we conducted two biodegradation experiments simultaneously. In experiment one, a given amount of substrate was added to the culture at the start of the experiment whilst in experiment two, the same amount of substrate was added, but using periodic pulses over the time course of the experiment. Three bacterial models, with different levels of complexity, (the Monod, Marr-Pirt and the dynamic energy budget - DEB - models), were used and calibrated using the above experiments. BGE has been estimated using the experimental values obtained from discrete samples and from model generated data. Cell maintenance was derived experimentally, from respiration rate measurements. The results showed that the Monod model did not reproduce the experimental data accurately, whereas the Marr-Pirt and DEB models demonstrated a good level of reproducibility, probably because cell maintenance was built into their formula. Whatever estimation method was used, the BGE value was always higher in experiment two (the periodically pulsed substrate) as compared to the initially one-pulsed-substrate experiment. Moreover, BGE values estimated without considering cell maintenance (Monod model and empirical formula) were always smaller than BGE values obtained from models taking cell maintenance into account. Since BGE is commonly estimated using constant experimental systems and ignore
\end{abstract}

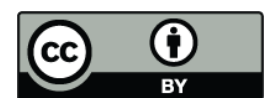

Correspondence to: R. Sempéré (richard.sempere@univmed.fr) maintenance, we conclude that these typical methods underestimate BGE values. On a larger scale, and for biogeochemical cycles, this would lead to the conclusion that, for a given DOC supply rate and a given DOC consumption rate, these BGE estimation methods overestimate the role of bacterioplankton as $\mathrm{CO}_{2}$ producers.

\section{Introduction}

Dissolved organic carbon (DOC) represents one of the largest active organic carbon reservoirs in the biosphere (Hedges, 1992; Amon and Benner, 1996). It is commonly assumed that numerous processes are responsible for DOC production such as its release by phytoplankton, egestion, excretion and sloppy feeding from grazers and cellular lysis generated by viruses (Nagata, 2000). Bacteria are considered to be the major consumers and remineralisers of DOC in the ocean (Pomeroy, 1974; Williams, 2000). According to bacterial reactivity, DOC is usually fractionated into three pools: the refractory (R-DOC), semi-labile (SL-DOC) and labile DOC (L-DOC) (Williams and Druffel, 1987; Carlson and Ducklow, 1995; Hansell et al., 1995). Bacterial activity is often measured using the bacterial growth efficiency (BGE). This is the proportion of DOC that is converted by bacteria into particulate organic carbon (POC) that can be later consumed by higher trophic levels (Cajal-Medrano and Maske, 2005). The L-DOC component and BGE can be determined by measuring the bacterial DOC consumption in biological assays (Carlson and Ducklow, 1996; Cherrier et al., 1996; Sempéré et al., 2003; Carlson et al., 1999). Both DOC production

Published by Copernicus Publications on behalf of the European Geosciences Union. 
and consumption occur in the natural environment through different processes, therefore any experimental design must endeavour to uncouple these two processes in order to study either one or the other. Consequently, such experiments are generally performed over 1-2 weeks either by isolating natural assemblages of bacteria from the primary producers and grazers by filtering in situ seawater samples, or by working with monospecific cultures.

It is generally assumed that the complementary proportion (1-BGE) corresponds to respiration and results in metabolic $\mathrm{CO}_{2}$ release in the ambient medium. BGE is commonly used as a constant parameter in biogeochemical models (BarettaBekker et al., 1995; Blackburn et al., 1996; Anderson and Williams, 1998, 1999; Lancelot et al., 2002), which are subsequently used to investigate the carbon cycle (Anderson and Williams, 1998, 1999). According to this, the general mathematical definition of BGE is: $B G E=\Delta B B /-\triangle D O C$, where $\triangle \mathrm{BB}$ is the bacterial biomass produced from the consumption of available $\triangle D O C$. However, BGE is generally determined experimentally from bacterial production (BP) and respiration (BR) measurements, or from $\mathrm{BP}$ and bacterial carbon demand (BCD) according to the following formula: $\mathrm{BGE}=\mathrm{BP} / \mathrm{BCD}$ where $\mathrm{BCD}=\mathrm{BP}+\mathrm{BR}$ (del Giorgio and Cole, 1998; Sempéré et al., 2003; Rivkin and Legendre, 2001; Reinthaler and Herndl, 2005). BGE may also be estimated from mathematical models as it often consists of a model parameter (Eichinger et al., 2006) or is a function of the specific growth rate (Cajal-Medrano and Maske, 1999, 2005).

Although biological assays provide a large set of BGE values, they are difficult to extend to real ecosystems due to the wide range of methods used and the utilisation of conversion factors which also exhibit large variations (Cherrier et al., 1996; del Giorgio and Cole, 1998). Despite this, previous studies have indicated that BGE varies greatly depending on biological and physical factors (del Giorgio and Cole, 1998) such as : DOC chemical nature/molecular weight (Amon and Benner, 1996; Cherrier et al., 1996), elemental ratio (Goldman et al., 1987), distance of the study site from the seashore (La Ferla et al., 2005), season (Reinthaler and Herndl, 2005), temperature (Rivkin and Legendre, 2001), depth (Eichinger et al., 2006) and UV exposure of dissolved organic matter prior to incubation (Abboudi et al., 2007). Moreover, batch experiments in which DOC monotonously decreases according to its consumption by bacteria are certainly not representative of the real world.

To date, to the best of our knowledge, there has been no study focusing on the direct effects of DOC availability on BGE. Indeed, due to physical, chemical, and biological processes (Carlson and Ducklow, 1995; Carlson et al., 2004; La Ferla et al., 2005), and to the decoupling between DOC production and consumption (Hansell et al., 1995; Carlson et al., 2002), the DOC concentration fluctuates spatially and temporally in oceanic ecosystems. Thus, relatively weak temporal variations in the dynamics of the water column may have a great impact on the functioning of the pelagic system
(González et al., 2002). This makes it crucial to study the response of microbial communities to intermittent or transient forms of reactive DOC (Cherrier and Bauer, 2004).

The first objective of this paper is to assess how the variation in DOC availability and supply affects BGE values using experimental and modelling approaches simultaneously. Most biogeochemical models use simplistic and empirical formulae to represent DOC consumption and bacterial growth, which are respectively described with MichaelisMenten kinetics and Monod formulation. Thus they do not take into account cell maintenance, the importance of which has been highlighted in several studies (del Giorgio and Cole, 1998; Eichinger et al., 2009). The second aim of this paper is to highlight the cell maintenance process using biodegradation assays and varying DOC supplies, in order to study how this affects BGE estimates. For this purpose, we have used several bacterial growth models with different levels of complexity, some considering cell maintenance: the Monod, Marr-Pirt and dynamic energy budget (DEB) models.

To meet these objectives, we performed two laboratory biodegradation experiments. In the first experiment, all the substrate was added at the beginning of the time series, whereas in the second experiment the same amount of substrate was divided into several smaller pulses and added to the culture every 2 days. Since the total quantity of substrate is the same at the end of both experiments, the only difference is the substrate regime.

This paper is organised as follows: in the first section we present a detailed description of the experiments carried out to assess the influence of the DOC load on BGE, and the various methods used for its estimation, including empirical calculations and model calibration. The different processes included in each model and their mathematical descriptions are given. The second section compares the experimental dynamics obtained from both experiments, and presents the calibration and simulation of the models. It also compares the BGE values estimated from both experiments, as obtained with each method. Finally, the last section presents the conclusions and discusses their implication for BGE determined in aquatic ecosystems.

\section{Material and methods}

\subsection{Main concepts}

To prevent problems arising from the sensibility of DOC measurements, the lability of DOC and bacterial activity, we used a monospecific bacterial strain and a highly labile carbon substrate source. Thus, we assumed that the decrease in DOC concentration is directly related to bacterial growth. We also applied an intensive sampling regime and used DOC concentrations well above oceanic conditions; the total L-DOC concentration added to the cultures was $8 \mathrm{mM}$ $\mathrm{C}$ whereas oceanic DOC concentrations generally range from 
$40 \mu \mathrm{M} \mathrm{C}$ to more than $200 \mu \mathrm{M} \mathrm{C}$. In this study, we defined LDOC as the substrate and thus the DOC that is consumed during the time course of the experiment (with a turnover time of a few hours, approximately) whereas R-DOC was considered to be the DOC accumulating and remaining at the end of the experiments. However, this R-DOC could consist of SL-DOC or R-DOC for our bacterial strain.

\subsection{Experimental design}

The culture medium was composed of artificial seawater (Lyman and Fleming, 1940), containing vitamins (Cobalamin: $0.5 \mu \mathrm{g} \mathrm{L}^{-1}$; Biotin: $5 \mu \mathrm{g} \mathrm{L}^{-1}$; Riboflavin, Pyridoxine, Folic acid, Nicotinic acid, Para-aminobenzoic acid: $50 \mu \mathrm{g} \mathrm{L}^{-1}$; Panthotenic acid, Meso-inositol: $500 \mu \mathrm{g} \mathrm{L}^{-1}$ ), minerals and excess nutrients at the beginning of each experiment; $\mathrm{KH}_{2} \mathrm{PO}_{4}$ and $\mathrm{NH}_{4} \mathrm{Cl}$ were provided at concentrations of 0.2 and $6.7 \mathrm{mM}$, respectively, and the $\mathrm{pH}$ was adjusted to 7.5. Pyruvate was selected as the carbon substrate and $\mathrm{Al}$ teromonas infernus as the bacterial strain (refer to Eichinger et al., 2009 for the explanations of these choices). Each medium was autoclaved for $20 \mathrm{~min}$ at $110^{\circ} \mathrm{C}$ prior to inoculation. The cultures were incubated in a temperate room at $25 \pm 1^{\circ} \mathrm{C}$, in the dark, and were continuously agitated. To prevent bacterial contamination, the material used to sample the batch cultures was sterilised by autoclaving $20 \mathrm{~min}$ at $110^{\circ} \mathrm{C}$, and all samples were handled under a laminar flow air hood. To prevent carbon contamination, all borosilicate glass materials used for the cultures and sample collection and storage were pre-combusted for $6 \mathrm{~h}$ at $450^{\circ} \mathrm{C}$. Cultures were not oxygenated, but incubation bottles were opened and shaken 3 to 4 times a day for sampling. This prevented oxygen depletion.

Two experiments were performed: one corresponding to a typical batch experiment using a single addition of substrate (SA), and one using pulse additions of substrate $(\mathrm{P})$. In the case of experiment $\mathrm{P}$, the initial conditions were: [DOC] $=1.6 \mathrm{mMC}$ and bacterial density $=6 \times 10^{6}$ cells cm ${ }^{-3}$ subsequently followed by pulse additions of DOC $(1.6 \mathrm{mMC})$ every $48 \mathrm{~h}$. The initial conditions set for experiment SA were: [DOC] $=8 \mathrm{mMC}$ (equivalent to $5 \times 1.6 \mathrm{mMC}$ ) and bacterial density $=6 \times 10^{6}$ cells $\mathrm{cm}^{-3}$. The initial conditions set for experiment $\mathrm{P}$ were chosen so that; (1) DOC decrease and bacterial growth were substantial, (2) the pulse period was long enough to allow sample collection between subsequent pulses, and (3) substrate DOC was apparently exhausted and bacteria were in the stationary phase at the end of the pulse period. This latter condition was necessary to observe cell maintenance when bacteria were in "starving" conditions.

The total volume of the culture enabled samplings to take place over 5 pulses. Both experiments were conducted in $5 \mathrm{~L}$ pre-combusted borosilicate bottles filled with 4 (experiment $\mathrm{P}$ ) or 3 (experiment SA) litres of culture medium. Because of the large volumes needed for sampling experiment $\mathrm{P}$,
3 replicate bottles were used and successively sampled. This setup made possible to use the same apparatus in both experiments. We checked reproducibility by carrying out the same experiment independently several times and checking the dynamics were always identical (data not shown).

\subsection{Sampling}

Sampling was always carried out in the same order to avoid bias from any time lag occurring between the different measurements. To prevent carbon contamination the first sub-sample was always dedicated to carbon measurements (DOC and POC). The sampling order was: (1) POC/DOC, (2) cell count by microscopy and flow cytometry analyses, and (3) oxygen consumption (respiration). To ensure reproducibility, samples were always further homogenised before sampling by gentle hand-mixing. To ensure the results were significant, the final volume of the batch cultures was always higher than $50 \%$ of the initial culture volume.

DOC and POC were separated using pre-combusted $\mathrm{GF} / \mathrm{F}$ filters $(0.7 \mu \mathrm{m}$ nominal porosity). After collection, DOC samples were acidified to $\mathrm{pH} \approx 1$ with $85 \%$ phosphoric acid and bubbled for $10 \mathrm{~min}$ with $\mathrm{CO}_{2}$-free air to purge inorganic carbon. DOC was measured by high temperature catalytic oxidation (HTCO) using a Shimadzu TOC 5000 analyzer following the same protocol as Sohrin and Sempéré (2005). Three or four $100 \mathrm{~mm}^{3}$ replicates of each sample were injected into the $680^{\circ} \mathrm{C}$ column. The coefficient of variation of DOC replicates was always smaller than $2 \%$. Quantification was performed using a four pointcalibration curve with standards (from 0 to $2 \mathrm{mMC}$ for experiment $\mathrm{P}$ and from 0 to $8.5 \mathrm{mMC}$ for experiment $\mathrm{SA}$ ) prepared by diluting potassium hydrogen phthalate in Milli-Q water. At time 0, the DOC measured was derived from the vitamins and pyruvate. The vitamin-DOC concentration was negligible compared to that of the pyruvate and estimated to account for only 3 and $0.6 \%$ of the initial DOC for the P and SA experiments, respectively.

In this study, we refer to POC as the C-bacterial biomass. A variable amount of culture was filtered at each sampling time in order to get a reliable POC signal (approximately $300 \mu \mathrm{g}$ of carbon on each filter). Following filtration onto the $\mathrm{GF} / \mathrm{F}$ filter, each filter was dried in an oven $\left(30^{\circ}\right)$ carefully stored in a desiccator in the dark and then analysed with a carbon analyzer (Leco SC-144) following the same protocol as Sempéré et al. (2000). Calibration was performed using a reference compound in the same order of magnitude as the sample. The measurement error was between 3 and $8 \%$ for these carbon concentrations.

$\mathrm{O}_{2}$ consumption was determined by measuring $\mathrm{O}_{2}$ concentration dynamics with the Oroboros-2k oxygraph (OROBOROS, Austria). This oxygraph provides the instrumental basis for temporal high-resolution respirometry due to a small time lag between two measurements $(2 \mathrm{~s})$. The sensitivity of this instrument is $<2 \mathrm{pmol} \mathrm{s}^{-1} \mathrm{~cm}^{-3}$ at a 
steady-state over $5 \mathrm{~min}$ at $20-40^{\circ} \mathrm{C}$, including any instrumental background correction (for more details please refer to http://www.oroboros.at). High cell concentrations are consequently needed to get adequate sensitivity and we utilised the same bacterial density for oxygen concentration measurements as for the cultures (bacterial densities ranged from $5.7 \times 10^{6}$ to $3.4 \times 10^{8}$ cells cm$^{-3}$ ). As recommended by the manufacturer the volume of the two thermoregulated chambers was set to $2 \mathrm{~cm}^{3}$, and the stirrer speed to 750 rounds per minute. Respiration measurements were carried out at $25^{\circ} \mathrm{C}$, the same temperature as the cultures. Each day, the basal consumption of each polarographic oxygen sensor (POS) was determined using a sterile medium sample. This value was then subtracted from each $\mathrm{O}_{2}$ consumption rate measured the same day. The POS were calibrated with 0 and $100 \%$ oxygen saturation. Zero percent oxygen saturation was achieved by adding anhydre sodium hydrosulfite $\left(\mathrm{Na}_{2} \mathrm{SO}_{3}\right)$ in excess, in order to complex all the oxygen in the chambers. The $100 \%$ oxygen saturation was calibrated prior to each measurement by introducing $2 \mathrm{~cm}^{3}$ of sterile culture medium to each chamber and keeping the stopper open to equilibrate the gas with the atmosphere. Once equilibrium had been reached, the $100 \%$ oxygen saturation was recorded. This sterile medium was then replaced by $2 \mathrm{~cm}^{3}$ of culture. As samples were in contact with atmospheric $\mathrm{O}_{2}$ prior to being introduced to the measurement chambers, we only used these data sets to extract $\mathrm{O}_{2}$ consumption rates at each sampling time. Incubations were carried out at the same time as other measurements and lasted for $15 \mathrm{~min}$. The first $10 \mathrm{~min}$ of $\mathrm{O}_{2}$ concentration results were discarded because the thermodynamic effects induced by the movement of the stopper when opening and closing the chambers were high enough to interfere with the measure of the bacterial respiration. We applied a linear regression to the recorded $\mathrm{O}_{2}$ concentration values over the next $200 \mathrm{~s}(3.3 \mathrm{~min})$ to calculate the $\mathrm{O}_{2}$ consumption rates. The slope values are reported for these regressions.

Bacterial density was estimated using microscopy counts to calculate specific bacterial activities (specific carbon content and $\mathrm{O}_{2}$ consumption). Bacteria fixation was carried out by adding $100 \mathrm{~mm}^{3}$ of a $20 \%$ tetraborated formol solution into $900 \mathrm{~mm}^{3}$ of culture. A few $\mathrm{mm}^{3}$ were taken out from this formol-mixture and added to filtered MilliQ water. The volume of the formol-mixture was adjusted according to the expected bacterial density, so that there were at least 30 bacteria per field under the microscope. Bacteria were stained with $4^{\prime}$,6-diamidino-2-phenylindole (DAPI) ( $2.5 \mu \mathrm{g} \mathrm{cm}^{-3}$ final concentration). The final mixture was filtered onto a $0.2 \mu \mathrm{m}$ porosity dark polycarbonate membrane. The counts (in cell $\mathrm{cm}^{-3}$ ) were carried out using an epifluorescence microscope (Olympus BH2 or BX61, Olympus, USA) by analysing 30 fields per sample.

In some samples bacterial density was also analysed using flow cytometry for total counts, and in the DOC samples to check for any bacterial transfer through the GF/F filters.
Bacterial fixation was carried out using $1.8 \mathrm{~cm}^{3}$ sample and $0.2 \mathrm{~cm}^{3}$ of a $20 \%$ para-formaldehyde (PFA) solution in $2 \mathrm{~cm}^{3}$ cryotubes (Nalgene, USA). Samples were then stored in liquid nitrogen $\left(-180^{\circ} \mathrm{C}\right)$ until analysis. Before analysis the samples were gently thawed in a water bath at room temperature, stained with DAPI solution $\left(2.5 \mu \mathrm{g} \mathrm{cm}^{-3}\right.$ final concentration) and analysed by a MoFlo cell sorter (Dako, Dk).

\subsection{BGE estimation}

According to the general definition, BGE can be estimated from experimental data as $\mathrm{BGE}=-\triangle \mathrm{POC} / \triangle \mathrm{DOC} . \triangle \mathrm{POC}$ was estimated from the difference between the maximum and initial POC values and $\triangle \mathrm{DOC}$ from the difference between the total substrate amount introduced in the culture $(8 \mathrm{mMC})$ and the remaining DOC amount at the end of the experiment.

BGE has also been estimated by using three models with different levels of complexity: the Monod, Marr-Pirt and Dynamic Energy Budget (DEB) models. For each model, BGE was estimated as: $\mathrm{BGE}=-d B / d L$, where $B$ is the bacterial biomass and $L$ the substrate concentration (L-DOC) (Table 1). The DEB model takes into account one C-reserve compartment as well as two C-maintenance fluxes (see below); the Marr-Pirt model considers one C-maintenance flux but no reserve compartment; the Monod model comprises neither reserve nor maintenance. Descriptions of state variables and parameters are given in Table 1. The DEB model originates from the dynamic energy budget theory (Kooijman, 2000). It has been specifically developed for the conditions in experiment $\mathrm{P}$ and its construction has been extensively described in Eichinger et al. (2009). For the sake of simplicity, we changed the model notation in this study to use symbols that fit more with biogeochemical studies. The differences from those used in Eichinger et al. (2009) and in this study are provided in Table 1. Briefly, the DEB theory assumes that bacterial biomass is composed of a reserve $(E)$ and structure $(V)$. Differential equations on the upper part of (Eq. 1) correspond to a typical growth model for heterotrophic bacteria, whereas differential equations on the lower part describe bacterial dynamics in starvation conditions. During growth, substrate is first assimilated into the reserve and then C-energy is allocated to growth. Maintenance is paid from the mobilized reserve if the flux is large enough (growth case). Otherwise, structure is used to pay the remaining part of the maintenance costs (starvation case), which causes size reduction of the cell (Tolla et al., 2007; Eichinger et al., 2009). Release of refractory-DOC $(R)$ was associated with the use of structure for maintenance purpose (Eq. 1). For this model: $\mathrm{BGE}=-\frac{d}{d L}\left(E / \mathrm{eff}_{E V}+V\right)$. Contrary to the DEB model, the Marr-Pirt model (Marr et al., 1963; Pirt, 1965) assumes a direct transfer from assimilation to growth and includes one maintenance term only. As this model does not comprise any reserve compartment, maintenance is directly realised from biomass (Eq. 2). As in the DEB model, $R$ is produced from the maintenance of 
the biomass. For this model, $\mathrm{BGE}=-d B / d L$. The Monod model (Monod, 1942) assumes that the absorbed substrate is directly and instantaneously transformed into biomass with a constant efficiency (Eq. 3) (Eichinger et al., 2006): $\mathrm{BGE}=-d B / d L$.

DEB model:

$$
\begin{aligned}
& \frac{d L}{d t}=-\alpha L V \\
& \text { if } k_{E} E>\operatorname{maint}_{E} V \\
& \left\{\begin{array}{l}
\frac{d E}{d t}=-\operatorname{eff}_{E L} \frac{d L}{d t}-\operatorname{maint}_{E} V-\operatorname{eff}_{E V} \frac{d V}{d t} \\
\frac{d V}{d t}=\frac{k_{E} E-\operatorname{maint}_{E} V}{E+\operatorname{eff}_{E V} V} V \\
\frac{d R}{d t}=0
\end{array}\right.
\end{aligned}
$$

if $k_{E} E<$ maint $_{E} V$

$$
\left\{\begin{array}{l}
\frac{d E}{d t}=-\operatorname{eff}_{E L} \frac{d L}{d t}-k_{E} E+\frac{d V}{d t} \frac{E}{V} \\
\frac{d V}{d t}=-\frac{\text { maint }_{E} V-k_{E} E}{E+\text { maint }_{E} V / \text { maint }_{V}} V \\
\frac{d R}{d t}=-\operatorname{eff}_{R V} \frac{d V}{d t}
\end{array}\right.
$$

Marr-Pirt model:

$$
\begin{aligned}
& \frac{d L}{d t}=-\alpha L B \\
& \frac{d B}{d t}=-\operatorname{eff}_{B L} \frac{d L}{d t}-\text { maint }_{B} B \\
& \frac{d R}{d t}=\operatorname{eff}_{R B} \operatorname{maint}_{B} B
\end{aligned}
$$

Monod model:

$$
\begin{aligned}
& \frac{d L}{d t}=-\alpha L B \\
& \frac{d B}{d t}=-\operatorname{eff}_{B L} \frac{d L}{d t}
\end{aligned}
$$

Note that in this study we also report that bacteria are able to produce DOC which accumulated over the time course of the experiments and is referred to here as R-DOC. The Monod model does not allow any product formation. Therefore, in order to compare parameters governing assimilation and growth on L-DOC between the three models, the DOC data were modified, for the utilisation of this model only (see below), to deal with just the labile fraction of DOC. In experiment SA, apparent R-DOC concentrations seem constant (Fig. 1a). L-DOC values were thus estimated by offsetting the R-DOC values at the end of the experiment to the total DOC values. In experiment $\mathrm{P}$, apparent R-DOC concentrations increased after each pulse and a linear regression on R-DOC values for all the experiment was applied (Fig. 1b). We calculated L-DOC values for the Monod model as $\mathrm{L}-\mathrm{DOC}=\mathrm{DOC}-(0.0038 t+0.1067)$, where DOC represents the measured DOC concentrations and $t$ is time. This data modification does not influence BGE values as it is only based on L-DOC and bacterial biomass (POC) data.
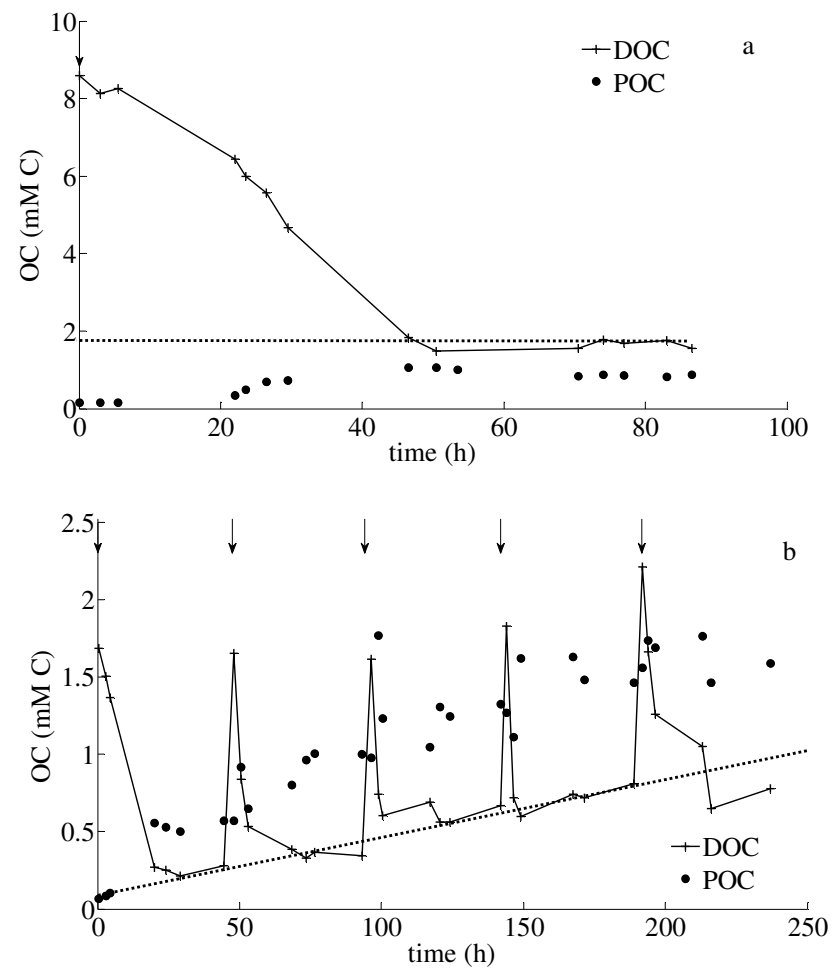

Fig. 1. Concentrations of dissolved and particulate organic carbon (DOC and POC, in mM C) measured in (a) the SA and (b) the P experiments. Arrows represent time when substrate was added to the cultures. DOC represents the substrate (pyruvate) plus all other DOC forms produced during the experiment, and POC represents the bacterial biomass. DOC dynamics are visualized by lines connecting the data points. Dotted lines = DOC accumulation throughout the experiment. $\mathrm{OC}$ is organic carbon.

\section{Results}

\subsection{DOC and POC dynamics}

Flow cytometry analyses revealed that the percentage of bacteria in DOC samples ranged from 0 to $14 \%$ in experiment SA. Higher values were obtained during the exponential growth phase, whereas this percentage was close to $0 \%$ during the lag and the stationary phases (data not shown). This suggests that bacteria are larger during the non dividing period, and that cell division leads to bacteria shrinking, subsequently reaching the size limit of the filter retention in some cases. We thus corrected POC and DOC concentration values according to the fraction of bacteria crossing the filters. In experiment $\mathrm{P}$, with the exception of two values of 11 and $13 \%$, the percentage of bacteria in DOC samples were always lower than $4.5 \%$. Unfortunately, some samples were not checked for bacterial density due to technical problems. Due to the low percentage found in analysed samples and to missing values, we decided not to correct DOC and POC values for experiment P. Experimental dynamics of 
Table 1. Symbols, units and descriptions of notations, state variables and parameters used in each model. As we modified model notation of the DEB model from Eichinger et al. (2009), we also indicated its symbols in the paper describing its construction.

\begin{tabular}{|c|c|c|c|c|c|c|}
\hline $\begin{array}{l}\text { Symbol in } \\
\text { this study }\end{array}$ & $\begin{array}{l}\text { Symbol in } \\
\text { Eichinger } \\
\text { et al. (2009) }\end{array}$ & Unit & Description & $\begin{array}{l}\text { Models } \\
\text { Monod }\end{array}$ & Marr-Pirt & DEB \\
\hline \multicolumn{7}{|c|}{ State variables } \\
\hline$L$ & $L$ & $\mathrm{mMC}$ & Substrate (L-DOC) concentration & $\mathrm{x}$ & $\mathrm{x}$ & $\mathrm{x}$ \\
\hline$E$ & $M_{E}$ & $\mathrm{mMC}$ & Reserve concentration & & & $\mathrm{x}$ \\
\hline$V$ & $M_{V}$ & $\mathrm{mMC}$ & Structure concentration & & & $\mathrm{x}$ \\
\hline$B$ & - & $\mathrm{mMC}$ & Bacterial biomass & $\mathrm{x}$ & $\mathrm{x}$ & \\
\hline$R$ & $R$ & $\mathrm{mMC}$ & $\begin{array}{l}\text { R-DOC (non-labile DOC) } \\
\text { concentration }\end{array}$ & & $\mathrm{x}$ & $\mathrm{x}$ \\
\hline \multicolumn{7}{|c|}{ Parameters } \\
\hline$V_{\max }$ & $j_{\mathrm{LAm}}$ & $\mathrm{h}^{-1}$ & $\begin{array}{l}\text { Maximum specific } \\
\text { substrate utilisation rate }\end{array}$ & $\mathrm{x}$ & $\mathrm{x}$ & $\mathrm{x}$ \\
\hline$K$ & $K$ & $\mathrm{mMC}$ & Half-saturation constant & $\mathrm{x}$ & $\mathrm{x}$ & $\mathrm{x}$ \\
\hline$\alpha=V_{\max } / K$ & $\alpha=j_{\mathrm{LAm}} / K$ & $\mathrm{mMC}^{-1} \mathrm{~h}^{-1}$ & Ratio between $V_{\max }$ and $K$ & $\mathrm{x}$ & $\mathrm{x}$ & $\mathrm{x}$ \\
\hline & $k_{E}$ & $\mathrm{~h}^{-1}$ & Reserve turnover rate & & & $\mathrm{x}$ \\
\hline $\operatorname{eff}_{E L}$ & $y_{M_{E} L}$ & - & $\begin{array}{l}\text { L-DOC assimilation } \\
\text { efficiency into reserve }\end{array}$ & & & $\mathrm{x}$ \\
\hline $\operatorname{eff}_{B L}$ & - & & $\begin{array}{l}\text { L-DOC assimilation } \\
\text { efficiency into biomass }\end{array}$ & $\mathrm{x}$ & $\mathrm{x}$ & \\
\hline $\operatorname{eff}_{E V}$ & $y_{M_{E}} M_{V}$ & - & $\begin{array}{l}\text { Efficiency of structure } \\
\text { transformation to reserve }\end{array}$ & & & $\mathrm{x}$ \\
\hline $\operatorname{eff}_{R V}$ & $y_{R M_{V}}$ & - & $\begin{array}{l}\text { Efficiency of R-DOC } \\
\text { production from structure }\end{array}$ & & & $\mathrm{x}$ \\
\hline $\operatorname{eff}_{R B}$ & - & - & $\begin{array}{l}\text { Efficiency of R-DOC } \\
\text { production from biomass }\end{array}$ & & $\mathrm{x}$ & \\
\hline maint $_{E}$ & $j_{M_{E} M}$ & $\mathrm{~h}^{-1}$ & Maintenance from reserve & & & $\mathrm{x}$ \\
\hline maint $_{B}$ & - & $\mathrm{h}^{-1}$ & Maintenance from biomass & & $\mathrm{x}$ & \\
\hline maint $_{V}$ & $j_{M_{V} M}$ & $\mathrm{~h}^{-1}$ & Maintenance from structure & & & $\mathrm{x}$ \\
\hline
\end{tabular}

DOC and POC take into account the correction for experiment SA (Fig. 1a) but not for experiment P (Fig. 1b).

DOC kinetics indicated an apparent remaining DOC during the time course of experiment $\mathrm{P}$ (Fig. 1b). Indeed, as represented by the dashed line in Fig. 1b, the baseline level for DOC concentration increased following each substrate addition. As hypothesised, bacteria always consumed the substrate added after each pulse, thus the increase in remaining DOC is not likely to be labile DOC for this strain. In this experiment we considered this "remaining-accumulating" DOC to be unconsumed DOC produced by the cultured bacteria and referred to it as R-DOC, over the scale of this study (refer to Eichinger et al., 2009, for additional details on this DOC production). On the contrary, no apparent R-DOC was produced over the time course of experiment SA; however, there was a DOC concentration of about $1.9 \mathrm{mMC}$ at the end of the experiment (Fig. 1a). As no substrate was added during this experiment, it is difficult to determine if this remaining DOC consisted of unconsumed substrate due to a limitation such as nutrients or $\mathrm{O}_{2}$, or whether the R-DOC was produced during another period of the experiment. We assumed this remaining DOC consisted of R-DOC, as in experiment $P$.

Over the entire experiment, about 6.1 and $7 \mathrm{mM}$ of DOC were consumed in the $\mathrm{P}$ and SA experiments, respectively. However, due to the very rapid reactivity of bacteria towards DOC supply in experiment $P$ and to the time lag necessary for DOC sampling following the additions, it is difficult to estimate the exact total concentration of DOC that was supplied in this experiment. It is therefore possible that the total concentration of consumed DOC is higher than that estimated for experiment $\mathrm{P}$. POC concentrations were identical at time 0 $(t 0)$ in both experiments. However, although the total concentration of substrate was the same in both experiments, the maximum POC concentrations differed. It reached a value of 1.8 and $1.1 \mathrm{mMC}$ for experiments P and SA, respectively. This suggests a higher productivity, of a factor of 1.6 for experiment $\mathrm{P}$. 


\subsection{Respiration rates dynamics}

$\mathrm{O}_{2}$ consumption rates varied from 0.02 to $0.61 \mathrm{mM} \mathrm{O}_{2} \mathrm{~h}^{-1}$ in experiment $\mathrm{P}$ and from $<0.01$ to $0.36 \mathrm{mM} \mathrm{O}_{2} \mathrm{~h}^{-1}$ in experiment SA. Because these rates are high, oxygen limitation needs to be taken into consideration. For this, we compared values of bacterial respiration obtained from the oxygraph to those obtained from calculating the mass balance. For experiment $\mathrm{P}$, we considered an average value for the respiration rate by the oxygraph, $0.25 \mathrm{mM} \mathrm{O}_{2} \mathrm{~h}^{-1}$ for the calculations. Using a simple model we simulated the oxygen dynamics within the culture setup where only diffusion and respiration rates were taken into account. The diffusion model is formulated as an equation of gas transfer (Maier and Büchs, 2001) from the headspace into the liquid phase (culture medium, where oxygen flux diffusion is proportional to oxygen saturation and concentration and where we experimentally estimated the diffusion rate to be $0.18 \mathrm{~h}^{-1}$ ). Using the oxygraph based respiration rates $\left(0.25 \mathrm{mM} \mathrm{O}_{2} \mathrm{~h}^{-1}\right)$ we estimated that cultures should be oxygen depleted after $1 \mathrm{~h}$ (data not shown). However, the cultured bacteria (Alteromonas infernus) is strictly aerobic and does not have a fermentative metabolism (Raguénès et al., 1997). This means that, if cultures were indeed limited by $\mathrm{O}_{2}$ after $1 \mathrm{~h}$, growth (POC increase) would stop; we did not observe this in our results (Fig. 1). Moreover, we did not observe any increase in growth following sampling, i.e. active oxygen input. Due to this strict aerobic metabolism, growth in our culture can only be achieved by substrate consumption and not by colimitation between the organic carbon and $\mathrm{O}_{2}$. If we then consider a broad mass balance over the whole culture experiment, where the apparent net DOC consumption $(\triangle \mathrm{DOC}$, e.g. carbon demand) results from the increase in biomass $(\triangle \mathrm{POC})$ and bacterial respiration $(\mathrm{BR})$, we can produce the following equation: $\mathrm{BR}=(\Delta \mathrm{DOC}-\Delta \mathrm{POC}) / \Delta t$ (where $t$ is time). For the whole experiment $\mathrm{P}, \triangle \mathrm{DOC}=6.1 \mathrm{mMC}$ and $\triangle \mathrm{POC}=1.8 \mathrm{mMC}$ over $240 \mathrm{~h}$, leading to $\mathrm{BR}=18 \mu \mathrm{MC} \mathrm{h}^{-1}$. By considering a respiratory quotient (RQ) equal to 1 , we obtained an apparent $\mathrm{O}_{2}$ consumption rate of $18 \mu \mathrm{M} \mathrm{O}_{2} \mathrm{~h}^{-1}$. For experiment $\mathrm{B}, \triangle \mathrm{DOC}=7 \mathrm{mMC}$ and $\triangle \mathrm{POC}=1.1 \mathrm{mMC}$ over $87 \mathrm{~h}$, leading to an apparent $\mathrm{O}_{2}$ consumption rate of $65 \mu \mathrm{MO}_{2} \mathrm{~h}^{-1}$. Using the same equation for the gas transfer rate previously described, and using these apparent $\mathrm{O}_{2}$ consumption rates, cultures would be at equilibrium $\left(\mathrm{O}_{2}\right.$ flux $=0$ between headspace and liquid phase) after $30 \mathrm{~h}$ in experiment $\mathrm{P}$ and would be $\mathrm{O}_{2}$ depleted after $5 \mathrm{~h}$ in experiment $\mathrm{B}$ (data not shown). However, as cultures were frequently aerated and shaken, $\mathrm{O}_{2}$ depletion certainly occurred later, if it occurred at all. Even if cultures were anoxic, growth could only be due to substrate consumption and co-limitation between organic carbon and oxygen does not seem to be a sustainable hypothesis.

By comparing both estimates for bacterial respiration (from oxygraph and from the mass balance equation) to our experimental results, we can assume that the $\mathrm{O}_{2}$ consumption

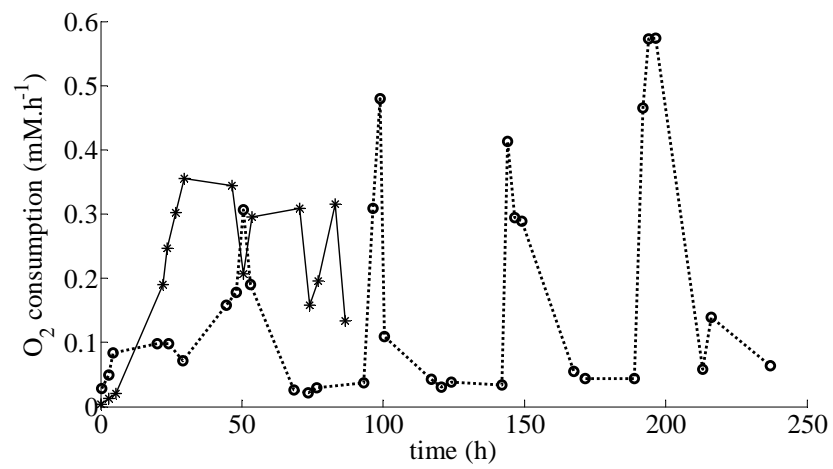

Fig. 2. Dynamics of $\mathrm{O}_{2}$ consumption $\left(\mathrm{mM} \mathrm{h}^{-1}\right)$ as calculated from the decrease in $\mathrm{O}_{2}$ concentration with an oxygraph at each sampling time during $200 \mathrm{~s}$ for the SA $(*)$ and the $\mathrm{P}(\bigcirc)$ experiment. Data points are connected by solid and dotted lines for the SA and $\mathrm{P}$ experiment, respectively.

rates estimated with the oxygraph give a measurement of potential respiration or maximal respiration $\left(R_{\max }\right)$. Indeed, oxygraph measurements showed that cultures were anoxic after $1 \mathrm{~h}$, which is not compatible with our experimental results (DOC consumption and POC increase) and A. infernus metabolism (aerobic). Consequently, oxygraph outputs can not be used to perform a mass balance exercise for the batch functioning, but these values may be used to estimate $R_{\max }$ and to compare their dynamics over an experiment. We can assume that oxygen limitation did not occur in our experiments and that the observed growth and DOC consumption were only due to substrate limitation. However, it could be possible, that at some point in time (for example few hours after substrate addition), $\mathrm{O}_{2}$ concentrations dropped to zero, and thus bacterial growth stopped. However, we do not have any accurate observations to demonstrate or refute this assumption. Another conclusion from this demonstration is that the accumulating DOC could not consist of L-DOC but rather of refractory DOC (R-DOC) produced by the cultured bacteria. Thus our estimated BGE really reflected growth efficiencies on the considered substrate. We may assume that at some point in time, cultures may have been anoxic, therefore the POC production and DOC consumption might have been underestimated in the same proportion, leading to a negligible biais in the BGE estimation.

In both experiments, $R_{\max }$ increased rapidly a few hours after $t 0$ (Fig. 2). However, this increase was more than 3 times higher for experiment SA: $R_{\max }$ peaked at 0.35 and $0.10 \mathrm{mM} \mathrm{O}_{2} \mathrm{~h}^{-1}$ for experiments SA and $\mathrm{P}$, respectively (Fig. 2). This difference is assumed to be due to the higher initial substrate concentration (x5) in experiment SA. The increase in $R_{\max }$ was slow in experiment SA, which correlates to the DOC degradation period (Fig. 1a). $R_{\max }$ then stabilised with only small variations around $0.25 \mathrm{mM} \mathrm{O}_{2} \mathrm{~h}^{-1}$. Respiration rates followed the DOC dynamics in experiment $\mathrm{P}$, increasing very rapidly following each substrate 

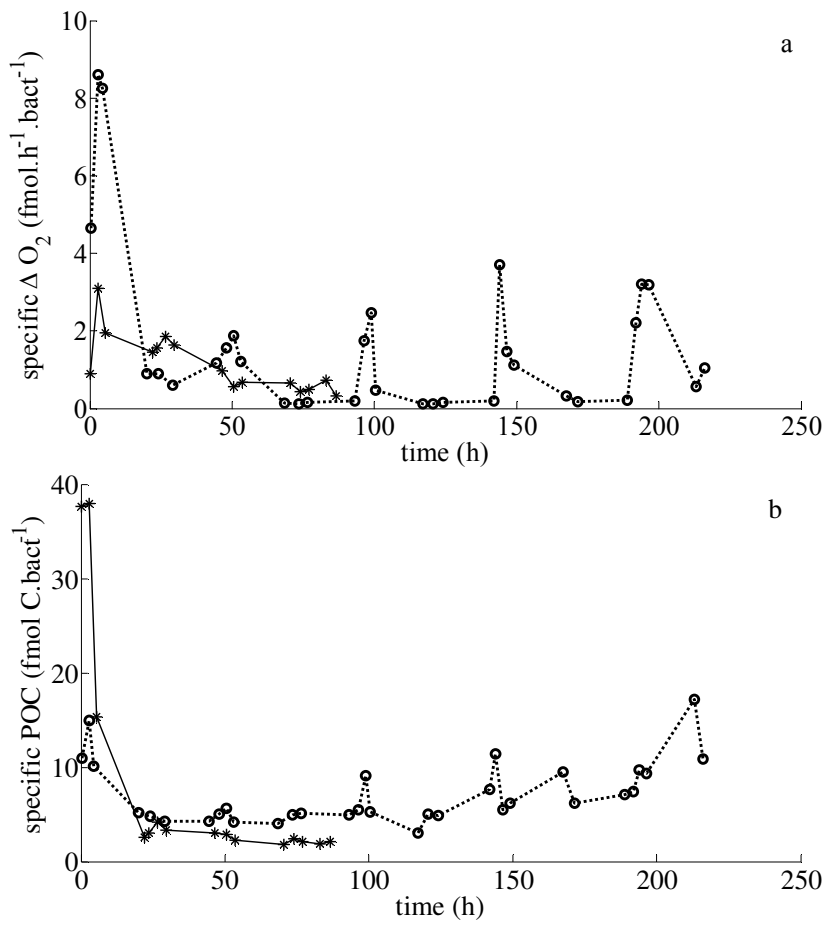

Fig. 3. Dynamics of (a) specific $\mathrm{O}_{2}$ consumption ( $\mathrm{fmol} \mathrm{h}^{-1}$ bact $^{-1}$ ) estimated as the ratio between $\mathrm{O}_{2}$ consumption rate and bacterial density and (b) specific POC ( $f m o l \mathrm{Cbact}^{-1}$ ) estimated as the ratio between POC concentration and bacterial density for the SA $(*)$ and the $\mathrm{P}(\mathrm{O})$ experiments. Data points are connected by solid and dotted lines for the SA and P experiment, respectively.

pulse, with higher values reaching $0.6 \mathrm{mM} \mathrm{O}_{2} \mathrm{~h}^{-1}$ (Fig. 2). Only a few hours after substrate addition, $R_{\max }$ decreased linearly never dropping to zero but stabilising at a constant value until the next substrate pulse. This constant value increased after each pulse as bacterial density increased throughout the experiment and demonstrated the maintenance process which can not be considered to be negligible. Using a trapezoidal integration method between the data points, we estimated a total potential $\mathrm{O}_{2}$ consumption about 30 and $20 \mathrm{mM} \mathrm{O}_{2}$ for the $\mathrm{P}$ and SA experiments, respectively. From this estimation, experiment $\mathrm{P}$ was 1.5 times more productive than experiment SA. Consequently, although a quantitative analysis could not be carried out using oxygraph measurements, observed $R_{\max }$ dynamics indicated an instantaneous response of bacteria to substrate pulses, a maintenance process between two subsequent pulses and greater consumption in experiment $\mathrm{P}$.

\subsection{Specific activities}

Specific $\mathrm{O}_{2}$ consumption ( $\mathrm{fmol} \mathrm{O}_{2} \mathrm{~h}^{-1}$ bact $^{-1}$ ) and specific organic-C content (fmol $\mathrm{C} \mathrm{bact}^{-1}$ ) were estimated by dividing $R_{\max }$ values and POC concentrations by their respective bacterial density at each sampling time (Fig. 3). Specific $\mathrm{O}_{2}$ consumption rapidly increased at t0 and then decreased in both experiments (Fig. 3a). In experiment SA, the specific respiration rate gradually decreased during the time course of the experiment. Contrary to this, the specific respiration rate sharply increased after each substrate addition and decreased a few hours later in experiment $\mathrm{P}$. Specific respiration rates dropped to a mean value of $0.2 \mathrm{fmol} \mathrm{O}_{2} \mathrm{~h}^{-1}$ bact $^{-1}$ between each subsequent pulse (and after the second pulse), a value which is an approximation of the potential specific maintenance respiration rate.

Although the initial POC concentration and bacterial density should be identical in both experiments, the initial specific organic-C contents were different, 38 and $11 \mathrm{fmol} \mathrm{Cbact}^{-1}$ for experiments SA and P, respectively (Fig. 3b). At $t 0$, each of the 3 bottles used for experiment $\mathrm{P}$ was sampled, but at $t 0$ we only reported measured values from the first bottle. Taking into account these 3 samples, we obtained specific POC values ranging from 11 to

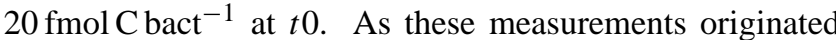
from the same initial culture, this difference may be due either to the measurement uncertainty, which might be higher for low POC concentrations, or to the difficulty of conducting accurate measurements at the onset of the experiment, due to low POC concentrations. The same conclusion applies when comparing the initial values of experiments $\mathrm{P}$ and SA. Then, the specific organic-C content rapidly decreased after

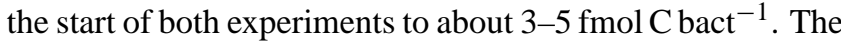
specific POC content then gradually decreased from approximatively 4 to $2 \mathrm{fmol} \mathrm{C}$ bact $^{-1}$ during the remaining time of experiment SA. Contrary to this, specific POC content increased after each substrate pulse in experiment $\mathrm{P}$ and was

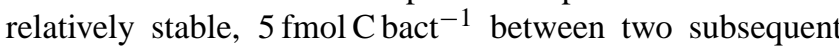
pulses. After $20 \mathrm{~h}$, specific POC values were always higher in experiment $P$ than in experiment SA (Fig. 3b).

\subsection{Model fitting}

The DEB, Marr-Pirt and, Monod models were calibrated from the data sets obtained from each experiment. Parameter estimation was based on the minimisation of the sum of squared deviations of model predictions to data points, using the Nelder Mead's simplex method. To compare model outputs to DOC and POC measurements, we made the following assumptions: (1) for the DEB model, $\mathrm{DOC}=L+R$ and $\mathrm{POC}=E+V$; (2) for the Marr-Pirt model, $\mathrm{DOC}=L+R$ and $\mathrm{POC}=B$; (3) for the Monod model, $\mathrm{DOC}=L$ and $\mathrm{POC}=B$. Calibrations were carried out using the whole original data set for experiment $\mathrm{P}$ and the whole corrected data set for experiment SA, as DOC and POC values were corrected for the bacteria that crossed the filters. The Monod model was calibrated with modified data sets from both experiments as we subtracted the estimated R-DOC concentrations from each DOC data point of each experiment. Estimated parameter values for each model are given in Table 2 for experiment SA and in Table 3 for experiment $P$. 
Table 2. Parameter values for each of the three models for experiment SA. POC and DOC data were corrected for bacteria passing through the filters. Parameters were estimated by the minimisation of the sum of squared deviations of model predictions to data points. As the Monod model cannot produce any release of nonlabile material, DOC concentrations were modified by subtracting the R-DOC concentration at the end of the experiment from each DOC data point.

\begin{tabular}{lccc}
\hline Parameters & Monod & Marr-Pirt & DEB \\
\hline$\alpha$ & 0.167 & 0.104 & 0.212 \\
$k_{E}$ & - & - & 0.201 \\
$\operatorname{eff}_{E L}$ & & - & 0.211 \\
eff $_{B L}$ & 0.142 & 0.203 & - \\
eff $_{E V}$ & - & - & 1.000 \\
$\operatorname{eff}_{R V}$ & - & - & 1.000 \\
$\operatorname{eff}_{R B}$ & - & 1.000 & - \\
maint $_{E}$ & - & - & 0.021 \\
maint $_{B}$ & - & 0.012 & - \\
maint $_{V}$ & - & - & 0.006 \\
\hline
\end{tabular}

The DEB and Marr-Pirt models fitted the DOC and POC data producing a good fit for both experiments (Fig. 4 a, b, d and e). However, the DEB model showed greater flexibility than the Marr-Pirt one. After data modification (represented by squares in Fig. 4c and f), the Monod model accurately fitted the DOC dynamics of both experiments, which can be explained by the fact that L-DOC uptake was governed by the same formulation in the three models. However, the Monod model did not produce a good fit for the POC data (Fig. 4c and f). We indeed prevented the problems associated with unconsumed DOC release as this process was not incorporated into the Monod model. However, the absence of the maintenance process did not enable the model to demonstrate the decrease in POC, which is clearly visible at the end of experiment SA.

\subsection{BGE estimations}

BGE was directly estimated experimentally as $\mathrm{BGE}=-\frac{\Delta \mathrm{POC}}{\Delta \mathrm{DOC}}$. $\quad \mathrm{BGE}$ was 0.14 and 0.27 for experiments SA and $\mathrm{P}$, respectively (Table 4), suggesting that bacteria were twice as efficient when provided with regular pulsed DOC inputs than when provided with a single DOC addition. BGE was computed for each experiment and each model (see Material and Method, BGE estimation). Whatever the estimation method, BGE values were constant over both experiments (Fig. 5). As was the case in the empirical estimation, BGE values were higher in experiment $P$ than in experiment SA: values were 0.34 and 0.21 for the DEB model, 0.38 and 0.20 for the Marr-Pirt model, and 0.23 and 0.14 for the Monod model. Growth efficiencies differed in the same range of magnitude for all estimations: BGE
Table 3. Parameter values for each of the three models for experiment P. Parameters were estimated by the minimisation of the sum of squared deviations of model predictions to data points. As the Monod model cannot produce any release of non-labile material, DOC data were modified to account for only the labile part of DOC by using the following equation: $\mathrm{L}-\mathrm{DOC}=\mathrm{DOC}-(0.0038 t+0.1067)$. This does not affect parameter and BGE estimations.

\begin{tabular}{|c|c|c|c|}
\hline Parameters & Monod & Marr-Pirt & DEB \\
\hline$\alpha$ & 0.364 & 0.347 & 0.484 \\
\hline$k_{E}$ & - & - & 0.603 \\
\hline $\operatorname{eff}_{E L}$ & - & - & 0.500 \\
\hline $\operatorname{eff}_{B L}$ & 0.234 & 0.382 & - \\
\hline $\operatorname{eff}_{E V}$ & - & - & 1.492 \\
\hline $\operatorname{eff}_{R V}$ & - & - & 1.000 \\
\hline $\operatorname{eff}_{R B}$ & - & 0.855 & - \\
\hline maint $_{E}$ & - & - & 0.000 \\
\hline maint $_{B}$ & - & 0.004 & - \\
\hline maint $_{V}$ & - & - & 0.008 \\
\hline
\end{tabular}

values were approximately 50\% higher in experiment $\mathrm{P}$ compared to experiment SA in both the experimental and Marr-Pirt estimations, and 60\% for the Monod and DEB estimations.

BGE estimations were always higher using the methods taking into account maintenance (DEB and Marr-Pirt models) compared to the Monod model and empirical estimations. The analytical calculations of BGE for the three models gave the following results: for the DEB model, $\mathrm{BGE}=\frac{\mathrm{eff}_{E L}}{\mathrm{eff}_{E V}}-\frac{\text { maint }_{E}}{\mathrm{eff}_{E V} \alpha L}$ (by taking only the growth model into account, otherwise we would obtain a negative BGE); for the Marr-Pirt model, $\mathrm{BGE}=\mathrm{eff}_{B L}-$ maint $_{B} / \alpha L$; and for the Monod model, BGE $=\mathrm{eff}_{B L}$ (Table 4). BGE for DEB and Marr-Pirt models depend on $L$, and should thus vary according to time. Finally, the parameter estimation showed that the variable parts of BGE (for Marr-Pirt and DEB models) were negligible: the constant values observed in Fig. 5 corresponded to the constant part of BGE (Table 4).

\section{Discussion}

\subsection{Maintenance process and model choice for bacterial growth}

Maintenance is generally defined as processes that do not produce new biomass but maintain cell integrity (CajalMedrano and Maske, 2005), which includes osmotic regulation, maintenance of intracellular $\mathrm{pH}$, futile cycles, turnover of macromolecules, motility and energy dissipation by proton leak and ATP hydrolysis (Pirt, 1965; Morita, 1997). In our study, respiration rate measurements enabled cell maintenance to be studied during the stationary phase. The 

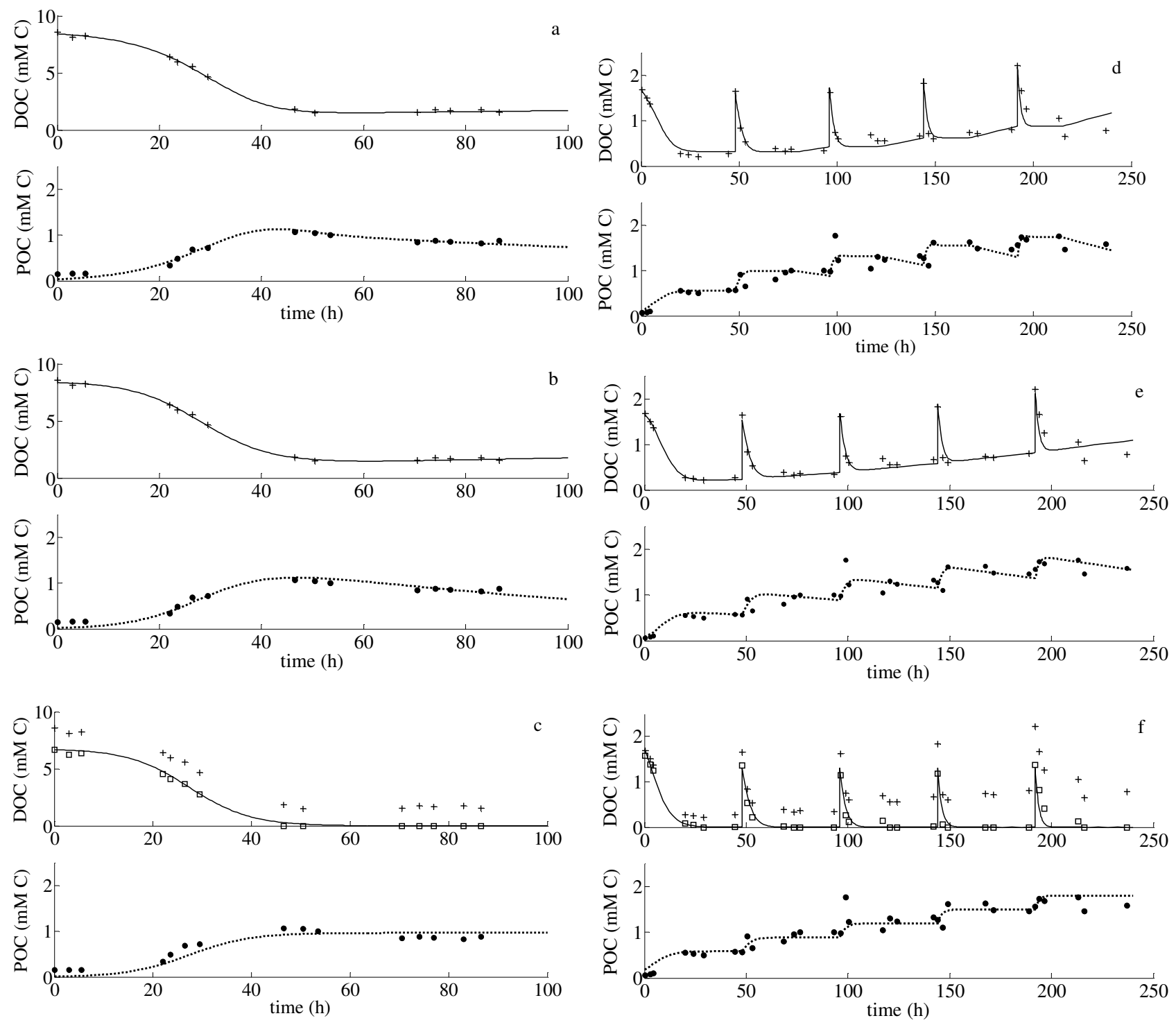

Fig. 4. Simulations of DOC (solid lines, mMC) and POC (dotted lines, mMC) concentrations for (a) the DEB, (b) Marr-Pirt and (c) Monod models for experiment SA and for (d) the DEB, (e) Marr-Pirt and (f) Monod models for experiment P. Model simulations are compared to experimental measurements of DOC $(+)$ and POC $(\bigcirc)$. Parameters of each model and for each experiment are provided in Tables 2 and 3. The Monod model was calibrated on and compared to modified DOC data to deal only with the labile part of DOC. This modified data set is represented by squares in panels $\mathrm{c}$ and $\mathrm{f}$.

Monod model is not suitable for this purpose. Indeed, it considers that a proportion BGE from assimilated substrate is used for growth, and implicitly that the remaining proportion (1-BGE) is used for respiration. However, when considering the equations, $\mathrm{L}=0$ would imply that the respiration rate (which amounts to $(1-\mathrm{BGE}) \alpha L B$ ) is also null. This result is inconsistent with our experimental results that clearly exhibited potential respiration rate values different from zero during starvation periods. The choice of a model is highly influenced by the available data. Indeed, if our experiments had been stopped after the growth phase and we had not measured the respiration rate, the Monod model would have reproduced the experimental data, which explains its wide utilisation for bacterial growth. Consequently, performing an experiment that continuously alternated between supply and depletion of substrate, coupled to respiration rate measurements, enabled us to reject the Monod model, when measuring bacterial growth in a fluctuating substrate supply, i.e. in fluctuating environments. Maintenance was not only observed from respiration rate measurements, but also from POC dynamics. Indeed, the decreasing POC concentrations during starvation periods strongly suggested the presence of such a process, which also eliminated the possibility of using the Monod model for bacterial growth. Previous studies 
Table 4. Summary of the different formulae used to estimate BGE, directly from data points (experimental) or with three models (Monod, Marr-Pirt and DEB models) for the SA and P experiments, and their corresponding values. The right side of the analytical formulae has been calculated with equations of each model (Eqs. 1-3). The last column represents parameters of each model to which BGE values corresponds analytically (see Fig. 5).

\begin{tabular}{|c|c|c|c|c|}
\hline $\begin{array}{l}\text { Method of BGE } \\
\text { estimation }\end{array}$ & Analytical BGE formula & $\begin{array}{c}\text { SA } \\
\text { experiment }\end{array}$ & $\begin{array}{c}\mathrm{P} \\
\text { experiment }\end{array}$ & $\begin{array}{l}\text { Parameter } \\
\text { equivalent with } \\
\text { BGE value }\end{array}$ \\
\hline Experimental & $\frac{\Delta \mathrm{POC}}{-\triangle \mathrm{DOC}}$ & 0.14 & 0.27 & \\
\hline Monod model & $\frac{d B}{-d L}=\operatorname{eff}_{B L}$ & 0.14 & 0.23 & $\operatorname{eff}_{B L}$ \\
\hline $\begin{array}{l}\text { Marr-Pirt } \\
\text { model }\end{array}$ & $\frac{d B}{-d L}=\operatorname{eff}_{B L}-\frac{\text { maint }_{B}}{\alpha L}$ & 0.20 & 0.38 & $\operatorname{eff}_{B L}$ \\
\hline DEB model & $\frac{d\left(E / \mathrm{eff}_{E V}+V\right)}{-d L}=\frac{\operatorname{eff}_{E L}}{\operatorname{eff}_{E V}}-\frac{\text { maint }_{E}}{\operatorname{eff}_{E V} \alpha L}$ & 0.21 & 0.34 & $\frac{\operatorname{eff}_{E L}}{\operatorname{eff}_{E V}}$ \\
\hline
\end{tabular}
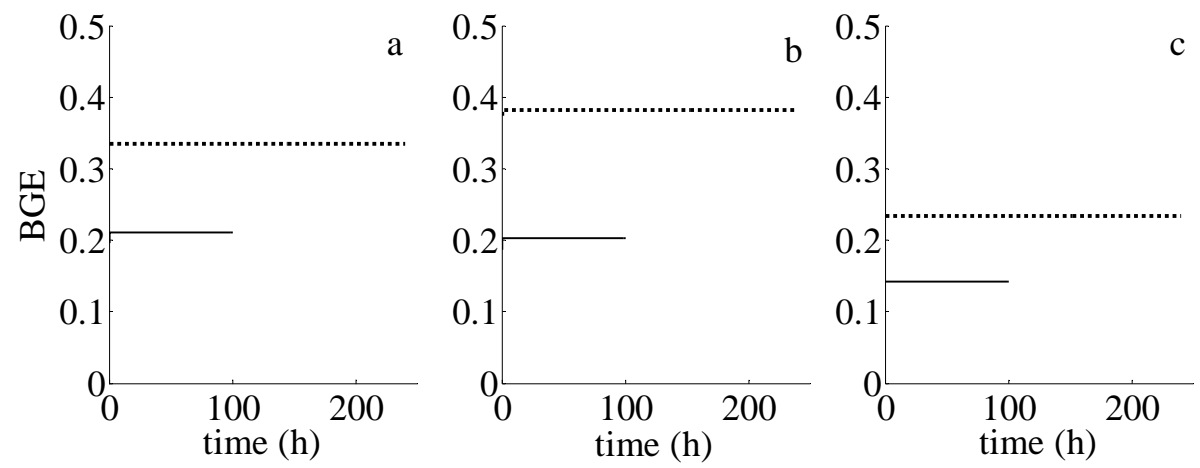

Fig. 5. Dynamics of BGE for the SA (solid line) and the $P$ (dotted line) experiments estimated with (a) the DEB, (b) Marr-Pirt and (c) Monod models. BGE were estimated as the ratio between the variation of the bacterial biomass and the variation of DOC. Their formula are summarised in Table 4.

have suggested the existence of bacterial (prokaryotic) maintenance in various ecosystems (Price and Sowers, 2004) and the need of including it in bacterial growth models. However, few studies clearly demonstrate this process at the cellular level with appropriate measurements as we did with respiration measurements. For instance, Cajal-Medrano and Maske (2005) demonstrated, using chemostat experiments, that the ratio of total $\mathrm{CO}_{2}$ to biomass decreased exponentially with specific growth rates without reaching 0 , suggesting the presence of maintenance respiration. This trend is well represented by the Marr-Pirt model, which included a constant maintenance respiration and a growth rate dependent respiration term. Cajal-Medrano and Maske (1999) utilised this model to explain the wide range of BGE reported for natural bacterioplankton. The fact that data from literature followed an asymptotic curve as expected from the Marr-Pirt model, with BGE approaching maximum values at higher growth rates, is proof of the existence of maintenance in natural bacterioplankton. Morita (1997) argued that bacterial survival under starvation conditions is not just one among many adaptations, but the fundamental aspect of bacterial existence, that most bacteria in most environments are experiencing most of the time. Consequently, nutrient flux to (and through) the cell surface and non-growth dependent energy consumption (maintenance) are an important consideration under these conditions (Konopka, 2000) and it is not conceivable to continue to use the Monod model for bacterial growth in ecosystem or biogeochemical models to study carbon fluxes in marine systems.

The formulation of the maintenance process seems to have little impact on model outputs in this study. Nevertheless, the DEB model is more flexible than the Marr-Pirt model due to its mechanistic formulation and can be validated in more diverse situations. One could likely appreciate the relevance of mechanistic approach by increasing the complexity of the experiment by including other trophic levels for example. 
It has been demonstrated using a food chain with bacteria, fed on glucose, and a predator, that the Monod and MarrPirt models were not able to reproduce the experimental dynamics, whereas the DEB model was (Kooi and Kooijman, 1994). Consequently, experimental developments, as those presented in this study, are needed in order to assess bacterial processes and should be included in ecosystem models. We could also observe dynamical differences between MarrPirt and DEB models if we had conducted a pulse experiment with the initial conditions of experiment SA and over a longer pulse period. The parameter maint ${ }_{E}$ constitutes one of the major differences between both models (Marr-Pirt model does not comprise any reserve compartment) and was negligibly low for experiment P. On the contrary maint $E$ was not negligibly low for experiment SA and was even higher than maintenance from structure $\left(\right.$ maint $\left._{V}\right)$. The Marr-Pirt model realised maintenance only from biomass $\left(\operatorname{maint}_{B}\right)$. Let us imagine a pulse experiment with the initial conditions of experiment SA over a longer pulse period, and with the parameter values of experiment SA for each model. Because in these

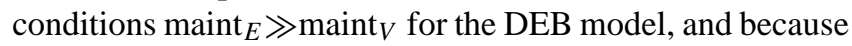
the Marr-Pirt model realised maintenance from biomass only, we could observe dynamical differences between both models, the Marr-Pirt model being unable to reproduce the experimental dynamics. van Bodegom (2007) reviewed the concept of maintenance and indicated that maintenance should not only include non-growth components, which explains why its quantification is in continuous debate, and should be dependent on several processes. Although we used a mechanistic formulation for maintenance as suggested by Tolla et al. (2007) and introduced two maintenance terms in our DEB model, we were able to compare growth expectations only with POC measurements. The addition of a respiration module in the DEB model would be of a great advantage in order to justify the use of such a model for microbes faced with such variable environments.

\subsection{Bacterial versatility to respond to a perturbation}

By estimating specific activities of bacteria faced to a pulsed substrate supply, we highlighted the versatility of bacterial metabolism, which would be difficult to observe in steadystate conditions. $\mathrm{O}_{2}$ concentration measurements revealed that respiration rates sharply increased as soon as substrate was introduced to the culture. This increase was so rapid that we probably underestimated potential $\mathrm{O}_{2}$ consumption due to the time lag between substrate addition in the culture, sampling, and respiration rate measurements. This conclusion is certainly true for DOC measurements, because if bacterial respiration rates increased so rapidly, they obviously consumed DOC very quickly after substrate addition. We may introduce the notion of population synchronisation as bacteria are constrained by the presence or absence of food. This synchronisation may be due to several factors, such as the stress generated by the absence of substrate and the large energy requirement for maintenance. Consequently, when we added substrate to the culture, the bacteria became simultaneously active to assimilate and grow, and cells continued maintenance even when the substrate was totally exhausted. This metabolic flexibility is necessary to cope with the in situ heterogeneity of a largely oligotrophic and ever-changing environment, and may result from the uncoupling of anabolic and catabolic processes (del Giorgio and Cole, 1998). We believe that the situation is the same in natural seawater, as food is not continuously available (Hanegraaf and Kooi, 2002) and bacteria may have to face long periods of absence of one or more nutrients (Konopka, 1999) and short periods of high substrate availability. Thus, by carrying out batch biodegradation experiments using in situ samples, bacteria may be in one or another situation. It is important to note that because bioassays often eliminate the effects of DOC production processes, these incubations only assess the standing stock of L-DOC at a given time (Raymond and Bauer, 2000). The resulting BGE values are obviously affected by the temporal variation of substrate availability and are finally not necessarily representative of the studied site. Therefore, extrapolating BGE values from incubations to the field may result in misrepresentation. Consequently, we have to be very cautious when comparing BGE from different study sites and periods, without considering the "history" of the water mass.

\subsection{Higher BGE in a realistically perturbed environment}

In this study, four constant BGE values (one empirical and three modelled BGE) differed, but they were always higher in the pulse experiment. Even if we consider that DOC consumption was largely underestimated in experiment $\mathrm{P}$, due to its rapid consumption following its addition to the culture, and took $\triangle \mathrm{DOC}=8 \mathrm{mMC}$ instead of $6.1 \mathrm{mMC}$, we still obtained BGE values higher for experiment $\mathrm{P}(0.23)$ than for experiment SA (0.14). It seems that bacteria were unable to efficiently grow when large amounts of substrate were present, whereas growth was stimulated when the same amount of substrate was added periodically. Results on higher BGE values in transient environments are consistent with the analysis of BGE values in diverse aquatic systems described in the literature. For instance, BGE values are higher in estuarine when compared to open ocean systems (del Giorgio and Cole, 1998). Indeed, estuarine systems are more influenced by episodic inputs of DOC compared to oceans. Raymond and Bauer (2000) reported a negative relationship between the L-DOC concentration and BGE in an estuarine system. This outcome could also mean that these higher BGE values resulted from a frequent input of L-DOC, but in a low concentration, which is unfortunately difficult to measure in situ. If considering oceanic systems, our results confirm those of Coffin et al. (1993) who reported a marked diel cycle, with BGE ranging from 37 to $72 \%$ and increasing during the day, presumably following inputs 
of algae derived organic substrates. Several authors have discussed temporal variations of BGE (Lemée et al., 2002; Reinthaler et al., 2005; Lee et al., 2009). They all estimated $\mathrm{BGE}$ as $\mathrm{BGE}=\mathrm{BP} /(\mathrm{BP}+\mathrm{BR})$, where $\mathrm{BP}$ was estimated either from bacterial abundance and $\mathrm{CCF}$ or from short incubations with ${ }^{3} \mathrm{H}$-leucine, and BR from the Winkler method with short incubation periods and an assumed RQ value of 1. Although study sites were clearly different (tropical coastal waters, open NW Mediterranean Sea and Southern North Sea) BGE ranged from $<1 \%$ to $43 \%$ for all studies. Maximal values were observed in September-October in surface waters of the NW Mediterranean Sea (Lemée et al., 2002) whereas BGE were maximum in spring in the Southern North Sea (Reinthaler et al., 2005). Factors regulating BGE seem to vary according to the study site: it has been shown that substrate quality was the most important factor regulating BGE in tropical coastal waters (Lee et al., 2009), whereas BGE was negatively correlated to bacterioplankton richness in the Southern Noth Sea (Reinthaler et al., 2005). Although numerous measurements were produced during each sampling in the NW Mediterranean Sea (nutrients, DOC concentration, chl a, primary production), regulatory mechanisms of BGE could not be identified in this investigation. Our results demonstrate that sudden variations in DOC concentration (the labile part of DOC) affect BGE values, which could be an explanation for the results of Lemée et al. (2002).

We also have demonstrated that BGE values were higher when maintenance was taken into account in the calculation. BGE are generally determined from bacterial production (BP) and respiration (BR) (from oxygen measurements, and converted into $\mathrm{CO}_{2}$ production with an assumed RQ) measurements in short incubation experiments. By definition, BP only takes production into account and thus no process that would lead to biomass decrease as maintenance. BR measurements are commonly made with incubations lasting a few hours, thus before bacteria are starving and before maintenance becomes the only remaining process. This would mean that these widely used methods underestimate BGE values. It is commonly assumed that the complementary proportion $(1-\mathrm{BGE})$ represents the fraction of DOC that is released as metabolic $\mathrm{CO}_{2}$ in the medium. This would finally lead to the conclusion that most of the previous studies investigating BGE using short incubation experiments and indirect/non integrative measurements might overestimate the role of bacteria as $\mathrm{CO}_{2}$ producers. It is thus important to take into account not only the spatial and temporal variability of DOC but also maintenance metabolism when assessing and quantifying the role of bacteria in the oceanic carbon cycle. We need to find a more consistent method for investigating bacterial growth and utilisation of DOC in natural environments in order to correctly compare results from different study sites and periods. By using a daily sampling strategy in the Pacific Ocean, during two periods in the spring and autumn, Carslon and Ducklow (1995) demonstrated the presence of a high frequency variability of bulk DOC, which is driven by physical processes. By using the same sampling strategy and carrying out degradation experiments on each water sample, one could examine the effect of this variability on bacterial metabolism and BGE.

\subsection{More consideration for estimating BGE}

In this study, the coupling of the experimental and modelling work made possible to estimate BGE values using two methods: the empirical (by calculating $\triangle \mathrm{DOC}$ and $\triangle \mathrm{POC}$ ) and the modelling methods (by calibrating three models on the data sets). However, most studies estimate BGE values via the utilisation of indirect methods by considering that $\mathrm{BCD}=\mathrm{BP}+\mathrm{BR}$ contrary to $\mathrm{BCD}=\triangle \mathrm{DOC}$. To estimate $\mathrm{BR}$, experimentalists generally apply a linear regression on the $\mathrm{O}_{2}$ dynamics and only consider the slope of this regression (del Giorgio and Cole, 1998; Eichinger et al., 2006). However, our experiments clearly demonstrated that the BR value varies greatly during an experiment, being high during assimilation and low during starvation periods. The non systematic linearity of BR, and its impact on BGE estimation, has already been demonstrated by performing continuous oxygen measurements with oxygen microprobes (Briand et al., 2004). This method also implies the utilisation of an assumed RQ value, which is generally unknown in the large variability of substrate used in the natural medium and which may vary over an experiment. BP is generally estimated from radiolabeled thymidine or leucine incorporation or by the difference between the final and initial bacterial abundances. However, these estimates rely on various conversion factors that have great uncertainties (Jahnke and Craven, 1995). BP estimation from bacterial abundance requires the utilisation of a carbon content factor (CCF) to go from bacterial density to bacterial biomass. In this study, we demonstrated that the CCF (defined as the specific POC content in this study), varied from 3 to $38 \mathrm{fmol} \mathrm{C}$ bact $^{-1}$ over an experiment. The mean CCF for marine bacteria is often considered to be $20 \mathrm{fg} \mathrm{C}$ bact $^{-1}$ (Lee and Fuhrman, 1987), corresponding to $1.7 \mathrm{fmol} \mathrm{C}$ bact $^{-1}$. Using this on our results would lead to an error of factor 20 when estimating bacterial carbon from bacterial density. Great variability in CCF values has been reported, depending on several factors. Bratbak (1985) found globally higher CCF in cultures of Pseudomonas putida (from 10.75 to $26 \mathrm{fmol} \mathrm{C} \mathrm{bact}^{-1}$ ) compared to mixed cultures of bacteria collected in an estuary ( 8.8 to $17.8 \mathrm{fmol} \mathrm{C} \mathrm{bact}^{-1}$ ). However, these values also varied according to limitation $(\mathrm{C}, \mathrm{N}$ or $\mathrm{P})$, being generally lower when cultures were $\mathrm{C}$ limited. In our experiments, the specific POC content always increased after substrate assimilation, reflecting the capability of bacteria to store carbon. It then decreased during starvation periods, until a "threshold" value. Vrede et al. (2002) also observed CCF variation in the growth phase, being larger during the exponential growth phase than during stationary phase. This would mean that CCF should be adapted to the physiological state of bacteria, which depends 
on substrate availability. It has also been shown that CCF is higher at higher temperatures (from $0.4 \mathrm{fmol} \mathrm{Cbact}^{-1}$ at

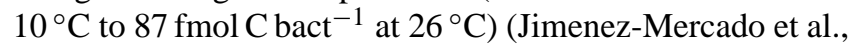
2007). This study also demonstrated that the BGE, directly calculated from changes in $\mathrm{POC}$ and $\mathrm{CO}_{2}$, increased with temperature. However, when the BGE was calculated using measured cell abundances and the commonly used CCF of $20 \mathrm{fg}$ C per cell (instead of the direct measurements of POC), the trend reversed. This demonstrated the difficulty of working with this conversion factor, especially as its value may vary in accordance with the environmental/experimental conditions.

\section{Conclusions}

Numerous studies have investigated how biological, chemical, and physical factors affect BGE values (del Giorgio and Cole, 1998). To the best of our knowledge, this is the first study demonstrating that the temporal variation in substrate availability greatly influences BGE, which may be twice as high in pulsed experimental conditions. Our simulated temporal variation of the DOC supply can simulate various biological factors occurring in situ, such as intermittent DOC release from phytoplankton and zooplankton, and transient physical forcing, as in turbulent eddies. This spatio-temporal variability of DOC distribution in the field would make BGE highly variable and makes it difficult to apprehend in situ. For instance, the methodology used in our study is difficult to implement in situ because analytical precision and accuracy of DOC measurements are insufficient and bacterial biomass could not be related to POC measurements. Moreover, the bacterial diversity, implying diversity of metabolisms, and the several DOC pools which could be produced and consumed simultaneously, make it difficult the comparison between in situ measurements and model state variables. However, the main results from our investigations are transposable to any situation: (1) in a system affected by frequent inputs of DOC/substrate, BGE will be higher than in a "one dose" system. Consequently, the estimation of BGE in such a transitory system with typical batch/incubation experiments would certainly be underestimated; (2) estimation of BGE with methods that did not take maintenance into account as the typical estimation with $\mathrm{BGE}=\mathrm{BP} /(\mathrm{BP}+\mathrm{BR})-$ also underestimated BGE values compared to methods that did (as the Marr-Pirt and DEB models here). More experiments are however required to confirm our results, for example measuring nutrient concentration and progressively incorporating more natural DOC sources. However, we should still consider the pulse load of substrate and other kinds of variable inputs. The outcome of this study is even more important knowing that model formulation and parameter estimation from experimental dynamics are often used in global models to investigate the oceanic carbon cycle.
Acknowledgements. The authors received financial support from the LMGEM research grant, from the French National Program for Coastal Environment (AMPLI Project) and Foundation TOTAL from the REMECCA program. PhD scholarships for M. E. came from the French Ministry of Research and Education. We would like to thank the Service Central d'Analyse du CNRS for POC analyses and the Regional Flow Cytometry Platform for Microbiology (PRECYM) on the Oceanology Centre of Marseille. Authors are grateful to M. Garel and A. Robert for their help in the experimental conception and realisation, and to T. Bentley for English corrections.

Edited by: G. Herndl

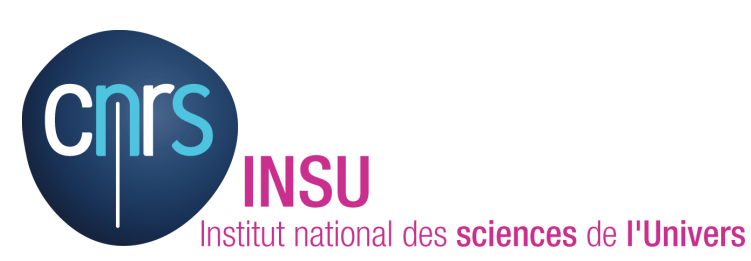

The publication of this article is financed by CNRS-INSU.

\section{References}

Abboudi, M., Jeffrey, W. H., Ghiglione, J.-F., Oriol, L., Sempéré, R., Charrière, B., and Joux, F.: Effects of photochemical transformations of dissolved organic matter on bacterial metabolism and diversity in three contrasting coastal sites in the northwestern Mediterranean sea during summer, Microb. Ecol., 55(2), 344357, doi:10.1007/s00248-007-9280-8, 2007.

Amon, R. M. W. and Benner, R.: Bacterial utilization of different size classes of dissolved organic matter, Limnol. Oceanogr., 41(1), 41-51, 1996.

Anderson, T. R. and Williams, P. J. L. B.: Modelling the seasonal cycle of dissolved organic carbon at station E-1 in the English Channel, Estuar. Coast. Shelf S., 46(1), 93-109, 1998.

Anderson, T. R. and Williams, P. J. L. B.: A one-dimensional model of dissolved organic carbon cycling in the water column incorporating combined biological-photochemical decomposition, Global Biogeochem. Cy., 13(2), 337-349, 1999.

Baretta-Bekker, J. G., Baretta, J. W., and Rasmussen, E. K.: The microbial food web in the European Regional Seas Ecosystem Model, Neth. J. Sea Res., 33(3/4), 363-379, 1995.

Blackburn, N., Zweifel, U. L., and Hagstrom, A.: Cycling of marine dissolved organic matter, II. A model analysis, Aquat. Microb. Ecol., 11(1), 79-90, 1996.

Bratbak, G.: Bacterial biovolume and biomass estimations, Appl. Environ. Microb., 49(6), 1488-1493, 1985.

Briand, E., Pringault, O., Jacquet, S., and Torréton, P.: The use of oxygen microprobes to measure bacterial respiration for determining bacterioplankton growth efficiency, Limnol. Oceanogr.Meth., 2, 406-416, 2004.

Cajal-Medrano, R. and Maske, H.: Growth efficiency, growth rate and the remineralization of organic substrate by bacterioplankton - revisiting the Pirt model, Aquat. Microb. Ecol., 19(2), 119$128,1999$. 
Cajal-Medrano, R. and Maske, H.: Growth efficiency and respiration at different growth rates in glucose-limited chemostats with natural marine bacteria populations, Aquat. Microb. Ecol., 38(2), $125-133,2005$

Carlson, C. A. and Ducklow, H. W.: Dissolved organic carbon in the upper ocean of the central equatorial Pacific Ocean, 1992: Daily and finescale vertical variations, Deep-Sea Res Pt. II, 42, 639-656, 1995.

Carlson, C. A. and Ducklow, H. W.: Growth of bacterioplankton and consumption of dissolved organic carbon in the Sargasso Sea, Aquat. Microb. Ecol., 10(1), 69-85, 1996.

Carlson, C. A., Bates, N. R., Ducklow, H. W., and Hansell, D. A.: Estimation of bacterial respiration and growth efficiency in the Ross Sea, Antarctica, Aquat. Microb. Ecol., 19(3), 229-244, 1999.

Carlson, C. A., Giovannoni, S. J., Hansell, D. A., Goldberg, S. J., Parsons, R., Otero, M. P., Vergin, K., and Wheeler, B. R.: Effect of nutrient amendments on bacterioplankton production, community structure, and DOC utilization in the northwestern Sargasso Sea, Aquat. Microb. Ecol., 30(1), 19-36, 2002.

Carlson, C. A., Giovannoni, S. J., Hansell, D. A., Goldberg, S. J., Parsons, R., and Vergin, K.: Interactions among dissolved organic carbon, microbial processes, and community structure in the mesopelagic zone of the northwestern Sargasso Sea, Limnol. Oceanogr., 49(4), 1073-1083, 2004.

Cherrier, J., Bauer, J. E., and Druffel, E. R. M.: Utilization and turnover of labile dissolved organic matter by bacterial heterotrophs in eastern north Pacific surface waters, Mar. Ecol.Prog. Ser., 139(1-3), 267-279, 1996.

Cherrier, J. and Bauer, J. E.: Bacterial utilization of transient plankton-derived dissolved organic carbon and nitrogen inputs in surface ocean waters, Aquat. Microb. Ecol., 35(3), 229-241, 2004.

Coffin, R. B., Connolly, J. P., and Harris, P. S.: Availability of dissolved organic carbon to bacterioplankton examined by oxygen utilization, Mar. Ecol.-Prog. Ser., 101, 9-22, 1993.

del Giorgio, P. A. and Cole, J. J.: Bacterial growth efficiency in natural aquatic systems, Annu. Rev. Ecol. Syst., 29, 503-541, 1998.

Eichinger, M., Kooijman, S. A. L. M., Sempéré, R., Lefèvre, D., Grégori, G., Charrière, B., and Poggiale, J. C.: DOC consumption and release by marine bacteria in pulsed-substrate environment: from experiments to modelling, Aquat. Microb. Ecol., 56(1), 41-54, 2009.

Eichinger, M., Poggiale, J. C., Van Wambeke, F., Lefèvre, D., and Sempéré, R.: Modelling DOC assimilation and bacterial growth efficiency in biodegradation experiments: a case study in the Northeast Atlantic Ocean, Aquat. Microb. Ecol., 43(2), 139-151, 2006.

Goldman, J. C., Caron, D. A., and Dennett, M. R.: Regulation of gross growth efficiency and ammonium regeneration in bacteria by susbtrate C:N ratio, Limnol. Oceanogr., 32(6), 1239-1252, 1987.

González, N., Anadón, R., and Marañón, E.: Large-scale variability of planktonic net community metabolism in the Atlantic Ocean: importance of temporal changes in oligotrophic subtropical waters, Mar. Ecol.-Prog. Ser., 233, 21-30, 2002.
Hanegraaf, P. P. F. and Kooi, B. W.: The dynamics of a tri-trophic food chain with two-component populations from a biochemical perspective, Ecol. Model., 152(1), 47-64, 2002.

Hansell, D. A., Bates, N. R., and Gundersen, K.: Mineralization of dissolved organic carbon in the Sargasso Sea, Mar. Chem., 51(3), 201-212, 1995.

Hedges, J. I.: Global biogeochemical cycles: Progress and problems, Mar. Chem., 39, 67-93, 1992.

Jahnke, R. A. and Craven, D. B.: Quantifying the role of heterotrophic bacteria in the carbon cycle - a need for respiration rate measurements, Limnol. Oceanogr., 40(2), 436-441, 1995.

Jiménez-Mercado, A., Cajal-Medrano, R., and Maske, H.: Marine heterotrophic bacteria in continuous culture, the bacterial carbon growth efficiency, and mineralization at excess substrate and different temperatures, Microb. Ecol., 54, 56-64, doi:10.1007/s00248-006-9171-4, 2007.

Konopka, A.: Theoretical analysis of the starvation response under substrate pulses, Microb. Ecol., 38(4), 321-329, 1999.

Konopka, A.: Microbial physiological state at low growth rate in natural and engineered ecosystems, Curr. Opin. Microbiol., 3, 244-247, 2000.

Kooi, B. W. and Kooijman, S. A. L. M.: The transient-behaviour of food-chains in chemostats, J. Theor. Biol., 170(1), 87-94, 1994.

Kooijman, S. A. L. M.: Dynamic energy and mass budgets in biological systems, 2nd edition, Cambridge University Press, Cambridge, 424 pp., 2000.

La Ferla, R., Azzaro, F., Azzaro, M., Caruso, G., Decembrini, F., Leonardi, M., Maimone, G., Monticelli, L. S., Raffa, F., Santinelli, C., Zaccone, R., and Ribera d'Alcalá, M.: Microbial contribution to carbon biogeochemistry in the Central Mediterranean Sea: Variability of activities and biomass, J. Mar. Syst., 57, 146$166,2005$.

Lancelot, C., Staneva, J., Van Eeckhout, D., Beckers, J. M., and Stanev, E.: Modelling the Danube-influenced north-western continental shelf of the Black Sea, II: Ecosystem response to changes in nutrient delivery by the Danube River after its damming in 1972, Estuar. Coast. Shelf S., 54(3), 473-499, 2002.

Lee, C. W., Bong, C. W., and Hii, Y. S.: Temporal variation of bacterial respiration and growth efficiency in tropical coastal waters, Appl. Environ. Microb., 75, 7594-7601, doi:10.1128/AEM.01227-09, 2009.

Lee, S. and Fuhrman, J. A.: Relationships between biovolume and biomass of naturally derived marine bacterioplankton, Appl. Environ. Microb., 53(6), 1298-1303, 1987.

Lemée, R., Rochelle-Newall, E., van Wambeke, F., Pizay, M. D., Rinaldi, P., and Gattuso, J.-P.: Seasonal variation of bacterial production, respiration and growth efficiency in the open NW Mediterranean Sea, Aquat. Microb. Ecol., 29, 227-237, 2002.

Lyman, J. and Fleming, R.: Composition of sea water, J. Mar. Res., 3, 134-146, 1940

Maier, U. and Büchs, J.: Characterisation of the gas-liquid mass transfer in shaking bioreactors, Biochem. Eng. J., 7, 99-106, 2001.

Marr, A. G., Nilson, E. H., and Clark, D. J.: The maintenance requirement of Escherishia coli, Ann. NY. Acad. Sci., 102, 536$548,1963$.

Monod, J.: Recherches sur la croissance des cultures bactériennes, Ph.D. thesis, University of Paris, Paris, France, 1942. 
Morita, R. Y.: Bacteria in oligotrophic environment: starvation survival lifestyle, Chapman \& Hall, New York, 529 pp., 1997.

Nagata, T.: Production mechanisms of dissolved organic matter, in: Microbial ecology of the oceans, edited by: Kirchman, D. L., Wiley-Liss, New York, 121-152, 2000.

Pirt, S. J.: The maintenance energy of bacteria in growing cultures, P. Roy. Soc. Lond. B Bio., 163, 224-231, 1965.

Pomeroy, L. R.: The ocean's food web, a changing paradigm, Bioscience, 24, 499-504, 1974.

Price, P. B. and Sowers, T.: Temperature dependence of metabolic rates for microbial growth, maintenance, and survival, P. Natl. Acad. Sci. USA, 101(13), 4631-4636, 2004.

Raguénès, G. H. C., Peres, A., Ruimy, R., Pignet, P., Christen, R., Loaec, M., Rougeaux, H., Barbier, G., and Guezennec, J. G.: Alteromonas infernus sp. nov., a new polysaccharide-producing bacterium isolated from a deep-sea hydrothermal vent, J. App. Microbiol., 82, 422-430, 1997.

Raymond, P. A. and Bauer, J. E.: Bacterial consumption of DOC during transport through a temperate estuary, Aquat. Microb. Ecol., 22, 1-12, 2000.

Reinthaler, T. and Herndl, G. J.: Seasonal dynamics of bacterial growth efficiencies in relation to phytoplankton in the southern North Sea, Aquat. Microb. Ecol., 39(1), 7-16, 2005.

Reinthaler, T., Winter, C., and Herndl, G. J.: Relationship between bacterioplankton richness, respiration, and production in the southern North Sea, Appl. Environ. Microb., 71(5), 22602266, doi:10.1128/AEM.71.5.2260-2266.2005, 2005.

Rivkin, R. B. and Legendre, L.: Biogenic carbon cycling in the upper ocean: Effects of microbial respiration, Science, 291(5512), 2398-2400, 2001.
Sempéré, R., Dafner, E., Van Wambeke, F., Lefèvre, D., Magen, C., Allegre, S., Bruyant, F., Bianchi, M., and Prieur, L.: Distribution and cycling of total organic carbon across the Almeria-Oran Front in the Mediterranean Sea: Implications for carbon cycling in the western basin, J. Geophys. Res.-Oceans, 108(C11), 3361, doi: 3310.1029/2002JC001475, 2003.

Sempéré, R., Yoro, S. C., Van Wambeke, F., and Charrière, B.: Microbial decomposition of large organic particles in the northwestern Mediterranean Sea: an experimental approach, Mar. Ecol.Prog. Ser., 198, 61-72, 2000.

Sohrin, R. and Sempéré, R.: Seasonal variation in total organic carbon in the northeast Atlantic in 2000-2001, J. Geophys. Res.Oceans, 110, C10S90, doi:10.1029/2004JC002731, 2005.

Tolla, C., Kooijman, S. A. L. M., and Poggiale, J. C.: A kinetic inhibition mechanism for maintenance, J. Theor. Biol., 244(4), 576-587, 2007.

van Bodegom, P.: Microbial Maintenance: A critical review on its quantification, Microb. Ecol., 53, 513-523, doi:10.1007/s00248006-9049-5, 2007.

Vrede, K., Heldal, M., Norland, S., and Bratbak, G.: Elemental composition $(\mathrm{C}, \mathrm{N}, \mathrm{P})$ and cell volume of exponentially growing and nutrient-limited bacterioplankton, Appl. Environ. Microb., 68(6), 2965-2971, 2002.

Williams, P. J. L. B.: Heterotrophic bacteria and the dynamics of dissolved organic material, in: Microbial ecology of the oceans, edited by: Kirchman, D. L., Wiley-Liss, New York, 153-199, 2000.

Williams, P. M. and Druffel, E. R. M.: Radiocarbon in dissolved organic-matter in the central north Pacific-Ocean, Nature, 330(6145), 246-248, 1987. 